Prima: Jurnal Pendidikan Matematika

Vol. 5, No. 2, July 2021, PP. 1 - 15

P-ISSN: 2579-9827, E-ISSN: 2580-2216

Web: http://jurnal.umt.ac.id/index.php/prima

\title{
ANALYSIS OF STUDENT'S MATHEMATICAL REASONING ABILITY IN SOLVING MATHEMATICAL PROBLEM BASED ON HOTS
}

\author{
Susi Herawati ${ }^{1}$, Puspa Amelia ${ }^{2}$ \\ ${ }^{1,2}$ Bung Hatta University \\ e-mail: susi.herawati@bunghatta.ac.id
}

\begin{abstract}
This study was focused on analyzing student's mathematical reasoning abilities in solving Higher Order Thinking Skill (HOTS) problems and determining the level of student understanding of HOTS questions. The research methods are qualitative and descriptive with 12 subjects. Based on the results of the test, the subject's reasoning abilities were grouped into 3 categories of reasoning abilities, namely high, moderate and low. The results showed that students who had high reasoning abilities were able to fulfill the 7 mathematical reasoning indicators very well at each stage of real analysis problem solving and were able to work on HOTS level questions to analyze and create. Students with moderate reasoning abilities were only able to fulfill several indicators of mathematical reasoning, namely presenting written statements, solving problems as planned and checking again. Students who had low reasoning abilities were not able to understand the questions well, so students cannot solve it. Based on the results of the questionnaire, it was concluded that $46.67 \%$ of students could understand the HOTS problem well, $33 \%$ of the students could not plan the solution, namely writing down the information that was known in answering the questions, and 33\% of the students were not able to check the validity of an argument and draw conclusions on the evidence. Furthermore, it was obtained the relationship between student's mathematical reasoning abilities and the level of student understanding of HOTS-oriented questions which fulfilled the linear regression equation $Y=71.574+$ 0.009X.This model showed that the level of student understanding of HOTS-oriented questions had a positive effect on learning outcomes. Based on the research results, it was suggested that lecturers provide more training related to proof with the aim of improving student's mathematical reasoning abilities.
\end{abstract}

Keywords: Reasoning, Mathematical, Understanding, HOTS.

\section{Abstrak}

Penelitian Ini bertujuan untuk menganalisa kemampuan penalaran matematis mahasiswa dalam pemecahan masalah Higher Order Thinking Skill (HOTS), dan mengetahui tingkat pemahaman mahasiswa terhadap soal HOTS. Metode penelitian adalah kualitatif dan deskriptif dengan subjek berjumlah 12 orang. Berdasarkan hasil tes kemampuan penalaran subjek dikelompokkan menjadi 3 kategori kemampuan penalaran yaitu tinggi, sedang dan rendah. Hasil penelitian menunjukkan bahwa mahasiswa yang memiliki kemampuan penalaran tinggi mampu memenuhi ke-7 indikator penalaran matematis dengan sangat baik pada setiap tahap pemecahan masalah analisis real dan mampu mengerjakan soal level HOTS menganalisis dan mengkreasi. Mahasiswa dengan kemampuan penalaran sedang hanya mampu memenuhi beberapa indikator penalaran matematis yaitu menyajikan pernyataan secara tertulis, menyelesaikan masalah sesuai rencana dan melakukan pengecekan kembali. Mahasiswa yang memiliki kemampuan penalaran rendah tidak mampu memahami soal dengan baik, sehingga mahasiswa tidak bisa menyelesaikannya. Berdasarkan hasil angket disimpulkan bahwa 46,67 \% mahasiswa dapat memahami masalah soal HOTS dengan baik, 33 \% mahasiswa tidak dapat merencanakan penyelesaian yaitu menuliskan informasi yang diketahui dalam menjawab soal, dan 33\% mahasiswa tidak mampu memeriksa kesahihan suatu argumen serta menarik kesimpulan atas pembuktian yang telah dikerjakan. Selanjutnya diperoleh hubungan antara kemampuan penalaran matematis mahasiswa dengan tingkat pemahaman mahasiswa terhadap soal berorientasi HOTS yang memenuhi persamaan regresi linear $\quad Y=71.574+0.009 X$. Model ini menunjukkan bahwa tingkat pemahaman mahasiswa terhadap soal berorientasi HOTS mempunyai pengaruh positif terhadap hasil belajar. Berdasarkan hasil penelitian disarankan agar dosen memberikan latihan lebih yang berkaitan dengan pembuktian dengan tujuan meningkatkan kemampuan penalaran matematis mahasiswa.

Kata kunci: Penalaran Matematis, Pemahaman, HOTS

Received: December 5, 2020; Revised: may, 2021; Accepted: July, 2021 


\section{INTRODUCTION}

Mathematics is formed because of human thoughts related to ideas, processes and reasoning. As stated by Corner, et al in (Abadiyah, 2016) that reasoning is very important in mathematics, both in learning mathematics and using mathematics. The purpose of Mathematics is that students have the ability to use reasoning on patterns and properties, perform mathematical manipulations in making generalizations, compile evidence, or explain mathematical ideas and statements.

According to (Suryadi, 2011) reasoning is a process or a thinking activity to draw a conclusion or a thought process in order to make a new true statement based on several statements whose truth has been proven or previously assumed. According to the Ministry of National Education, mathematics material and mathematical reasoning are two inseparable things (Fajar, 2014). Mathematical material is understood through reasoning, and reasoning is understood and trained through learning mathematics. Meanwhile, Copi in (Suryadi, 2011) states, "Reasoning is a special kind of thinking in which inference takes place, in which conclusions are drawn from premises". Mathematical reasoning is a habit of thought and must be developed consistently in various contexts (Adamura \& Susanti, 2018; Dosinaeng, 2019). The development of reasoning skills requires learning that facilitates the thinking process, reasoning process, student's critical attitude and questioning. Learning that is carried out to develop student's mathematical reasoning is designed according to student's reasoning abilities. From the description above, it can be concluded that critical, creative thinking and reasoning processes are categorized as HOTS (higher order thinking skills).

High-level thinking skills (HOTS), logical, critical thinking and reasoning skills are basic skills in everyday life, besides academic skills (Adamura \& Susanti, 2018). High-level thinking skills and mathematical reasoning are one of the individual assets to prepare themselves for the 4.0 industrial revolution, where students are required to be skilled in solving complex problems, critical and creative thinking. A person's critical thinking ability can be seen through the ability to solve mathematical problems. According to (Dosinaeng, 2019), someone who thinks critically and creatively will be able to solve problems better because he or she is able to understand more deeply the problems at hand, make plans more precisely and creatively, carry out plans in more detail and be better able to re-examine their work. which is based on its ability to evaluate and self-regulate. 
Higher order thinking skills (HOTS) is a hot topic discussed in the world of education. The issue is concern at this time is the low level of high-level thinking skills of Indonesian students, as shown by the results of the international study of PISA (Program forlnternational Student Assessment) (Dosinaeng, 2019). Rustandi in (Suryadi, 2011) states that the 2003 TIMSS test results show that Indonesian students were ranked 35th out of 46 countries, especially in the field of mathematical reasoning.

Higher Order Thinking Skill (HOTS) is a thinking process of learners at a higher cognitive level that is developed from various cognitive concepts and methods and learning taxonomies such as problem solving methods, bloom taxonomy, and learning, teaching, and assessment taxonomies. HOTS includes problem solving skills, creative thinking skills, critical thinking skills, argumentation skills, and decision making skills.

A person's ability to think critically and creatively can be seen through the ability to solve mathematical problems. A person who thinks critically and creatively will be able to solve problems better because he is able to understand more deeply the problems at hand, plan more precisely and creatively, carry out plans in more detail and be better able to reexamine his work based on his ability to evaluate and self-regulating.

\section{The Student's Understanding of HOTS Questions}

The quality mathematics learning is absolutely necessary in an effort to develop understanding abilities. The ability to understand mathematics is one of the important goals in learning, which means that the material taught to students is not only memorization but also understanding, so that students can understand the concept of the subject matter it self. According to (Keller et al., 2001) "Problem solving central to inquiry and application and should be inter woven throughout the mathematics curriculum to provide a context for learning and applying mathematical ideal". This opinion states that problem solving skills are the main thing needed in the discovery and application activities that must be woven through out the mathematics curriculum to provide a context for learning and applying mathematical ideas.

Polya gave an opinion on solving the problem as follows Polya suggested consist of four phases: "understanding the problem, devising a plan, carriying out the plan, and looking back". Based on Polya's opinion above, there are four components in problem- 
solving abilities, namely understanding the problem, making plans, implementing plans, and checking again. Polya's problem solving was useful and interasting thought the students encountered some difficulties in the course (Phuntsho \& Dema, 2019). Without an understanding of the problem given, students may not be able to solve the problem correctly. After students can understand the problem correctly, then they must be able to develop a problem-solving plan. The ability to do this second step really depends on the student's experience in solving problems. If a problem resolution plan has been made, either in writing or not, then the problem will be resolved according to the plan deemed the most appropriate. The final step in the problem-solving process according to Polya is to check what has been done starting from the first step to the last step. The advantage of the problem-solving system based on the steps proposed by Polya is that Polya's steps provide a neatly structured framework for solving complex problems so that it can help someone to solve problems.

Susan Brookhart categorizes the top three cognitive processes in Bloom's taxonomy, namely analyzing, evaluating, and creating as critical level thinking processes (Keller et al., 2001).

\section{METHODS}

The research method is qualitative descriptive with 12 subjects. The participants in this study were 12 students who had taken real analysis course. From the reasoning test result, then the subjects were divided into 3 groups, namely high, moderate and low test score based on the following steps [6] :

1. Calculate the difference between the highest and lowest scores from the test results

$$
X=X_{\max }-X_{\min }
$$

2. Calculate the number of interval classes with equations,

the number of class $=1+3,3 \log n ; n=$ number of data

3. Determine the length of the interval by dividing the range by many classes

4. Determine the mean with equations

$$
M_{x}=\frac{\sum F_{i} X_{i}}{\sum F_{i}}
$$

5. Determine the standard deviation with equations

$$
S D_{x}=\sqrt{\frac{\sum F_{i} X_{i}^{2}}{\sum F_{i}}-\left(\frac{\sum F_{i} X_{I}}{\sum F_{I}}\right)^{2}}
$$


6. Counting (mean $+\mathrm{SD})$ and (mean-SD)

7. Classifying the reasoning abilities with the criteria as follows:

Table 1. The Criterian of Grups Grouping

\begin{tabular}{|l|c|}
\hline \multicolumn{1}{|c|}{ Grouping Criteria } & Cognitif Groups \\
\hline Nilai $\geq$ mean + SD & High \\
\hline Mean - SD $\leq$ nilai $<$ mean + SD & Moderate \\
\hline Nilai $<$ mean - SD & Low \\
\hline
\end{tabular}

To obtain deeper data on mathematical reasoning, two high-ability students $(S 4, S 6)$ were selected, three medium-ability students $(\mathrm{S} 1, \mathrm{~S} 7)$, and two low-ability students $(\mathrm{S} 2, \mathrm{~S} 5)$. The 6 subjects were taken using a purposive technique, namely: (1) examining the results of student work, (2) grouping the uniqueness of the answers to the questions given based on Polya's problem solving stages.

Mathematical reasoning ability was measured by using indicators according to (Adamura \& Susanti, 2018), namely (1) Ability to present mathematical statements verbally, in writing, pictures, and diagrams, (2) ability to propose assumptions, (3) ability to perform algebraic manipulation, (4) Ability draw conclusions, compile evidence, provide reasons or evidence for several solutions, (5) the ability to draw conclusions from statements, (6) the ability to check the validity of an argument, and (7) the ability to find patterns or properties ofmathematical symptoms to make generalizations.

Meanwhile, the ability to solve problems used the Polya stages in [6], namely: (1) understanding the problem; (2) prepare plans and implement plans; and revisiting (Phuntsho \& Dema, 2019). The real analysis problem in this study is limited to the following problems: (1) function, absolute value, real number sequence properties and completeness of real numbers.

The instruments used for data collection were tests and questionnaires. The number of subjects who filled out the questionnaire was 12 people. The test consists of 5 HOTS-oriented questions, covering analyzing, evaluating, and creating. The questionnaire was created using the google form website and given to the subject and filled out online via the http://www.docs.google.com page with the link https://docs.google.com/forms/d/1kk13UX vc4EQUwVIsQ7NjA9C9VhnWvSkdF44ore40/prefill. 
Reasoning data obtained from the test results were analyzed using analysis techniques by Miles \& Huberman in (Sugiyono, 2013), namely: (1) data reduction; (2) data presentation; and (3) data verification. Meanwhile, to see the relationship between mathematical reasoning and students' understanding of HOTS-oriented questions, the analysis uses the SPSS program.

\section{RESULTS AND DISCUSSION}

Based on the results of the reliability and validity test, it was found that the questionnaire instrument had a cronbach alpha of 0.668 and a KMO value of 0.506 , so it could be concluded that the questionnaire instrument for students' understanding of HOTSoriented questions was reliable and valid. In the HOTS problem, only content validation was carried out, which aims to see the suitability of the question material with the theory of the Bloom Stages stages, namely, analyzing, evaluating, and creating (As'ari et al., 2019). From the results of the question analysis it can be said to be valid. Beside that, from the questionnaire analysis using the SPSS application with the Kolmogorov Smirnov test with Alpha 0.05, data were normally distributed. Then, data was analyzed by using regression analysis.

\section{Relationship between Student's Mathematical Reasoning Ability and Student's Understanding Level of HOTS Oriented Questions.}

\begin{tabular}{|c|c|c|c|c|}
\hline \multirow[t]{2}{*}{ Model } & \multicolumn{2}{|c|}{ Unstandardized Coef } & \multirow[t]{2}{*}{$\mathbf{t}$} & \multirow[t]{2}{*}{ Sig } \\
\hline & B & Std Error & & \\
\hline Constant & 71,574 & 3,782 & 18,927 & 0 \\
\hline $\mathrm{X}$ & 0.009 & 0,091 & 5,010 & 0,002 \\
\hline
\end{tabular}

Based on Table 2, the regression coefficient value of the research variables can be substitutedinto the simple linear regression equation, namely

$$
Y=71.574+0.009 X
$$

The linear regression model above showed that the level of student understanding of HOTSoriented questions has a positive effect on student learning outcomes. Furthermore, the regression coefficient of the above model is 0.009 . This shows that student learning outcomes will increase if the level of student understanding of HOTS questions also increases by 0.009 . 
Based on table 1 also obtained t-count of 5.010 , while the $p$-value (sig t) is 0.002 , so that the sig $t<0.05$. This shows that there is a significant influence between the level of student understanding of HOTS-based problem solving problems with student learning outcomes. Thus it can be concluded that the higher the level of student understanding of HOTS questions, the student learning outcomes will be better too. Furthermore, the coefficient of the regression model is 0.009 . This shows that student learning outcomes will increase if thelevel of student understanding of HOTS questions also increases by 0.009 .

Table 3. The Determination Coefficient For Linier Regression Model

\begin{tabular}{llllll}
\hline Model & R & R Square & $\begin{array}{l}\text { Adjusted } \\
\text { R Square }\end{array}$ & $\begin{array}{l}\text { Std. } \\
\text { Error of } \\
\text { the } \\
\text { Estimate }\end{array}$ & $\begin{array}{l}\text { Durbin- } \\
\text { Watson }\end{array}$ \\
\hline 1 & .032 & .001 & -.099 & 546.461 & 1.943 \\
\hline
\end{tabular}

Based on table 3, it can be seen that the R-square value is 0.001 . This shows the magnitude of the influence of understanding HOTS questions on student's mathematical reasoning abilities is $0.1 \%$ and the remaining $99.9 \%$ is influenced by other variables not included in the research model.

Table 4. The F-Count of Linier Regression Model

\begin{tabular}{|c|c|c|c|c|c|c|c|}
\hline \multicolumn{2}{|c|}{ Model } & \multirow{2}{*}{$\begin{array}{l}\begin{array}{l}\text { Sum } \\
\text { Squares }\end{array} \\
.297\end{array}$} & \multirow{2}{*}{ of } & \multirow{2}{*}{$\begin{array}{l}\text { df } \\
1\end{array}$} & \multirow{2}{*}{$\begin{array}{l}\text { Mean } \\
\text { Square } \\
.297\end{array}$} & \multirow{2}{*}{$\begin{array}{l}\mathbf{F} \\
5.010\end{array}$} & \multirow{2}{*}{$\begin{array}{l}\text { Sig. } \\
.002^{b}\end{array}$} \\
\hline & Regression & & & & & & \\
\hline \multirow[t]{2}{*}{1} & Residual & 298.619 & & 10 & 29.862 & & \\
\hline & Total & 298.917 & & 11 & & & \\
\hline
\end{tabular}

Based on the data analysis in table 4, it is known that the calculated $\mathrm{F}$ value is $\mathbf{5 . 0 1 0}$ with a significance value of 0.002 , which means that the significance value is smaller than alpha $(0.002<0.05)$. This shows that the resulting regression model is a valid predictor in estimating the dependent variable. Partial correlation coefficient is a value that describes the partial relationship between one variable and another variable by assuming other variables outside the two variables are constant.

Based on the overall calculation of the above data and hypothesis testing, it can be concluded that there is a relationship between the level of student understanding of HOTSoriented questions and mathematical reasoning abilities. The results of this study also strengthen the results of the study by (Hakima et al., 2019; Hanifah et al., 2019) to solve 
HOTS-based math problems. From the result (Hanifah et al., 2019) concluded that there is a positive relationship between reasoning abilities and learning motivation.

\section{Mathematical reasoning of subjects who have high reasoning skills in solving HOTS-based math problems}

Overall, the S-4 and S-6 subjects can be said to be able to solve the HOTS-based real analysis test questions. They have been able to solve problems at the creative and analyzing level, except for question 5, the subject has not been able to provide examples of functions. Meanwhile, in problem 4, S-4 could not determine the set of solutions from the absolute value. Figure 1 shows a snippet of the written answer to the S-4 subject in question 4 .

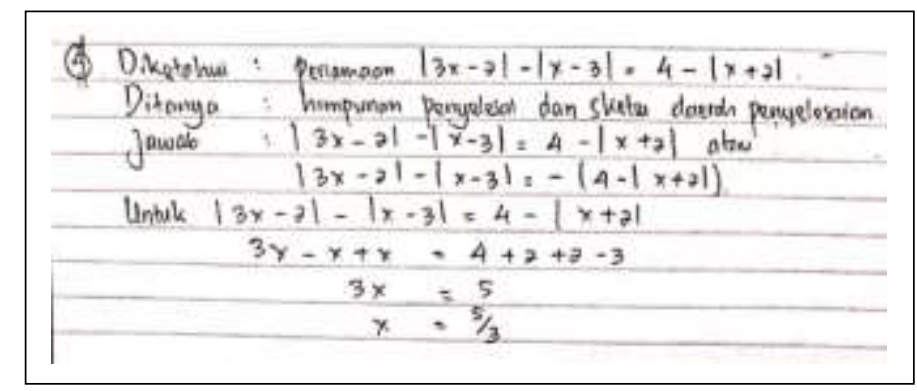

Figure 1.Test Result of S4 at Number 4

Based on the problem solving written by subject S4, it can be seen that the subject has rewritten what is known and asked by the question, namely $|3 x-2|-|x-3|=4-|x+2|$. However, the subject did not write down the definition of absolute value first, so the subject was wrong in defining the absolute value equation, written $|3 x-2|-|x-3|=-(4-|x+2|)$. The subject should define the three absolute values contained in the equation, namely $\mid 3 x-$ $2|| x-,3|| x+2 \mid$, .

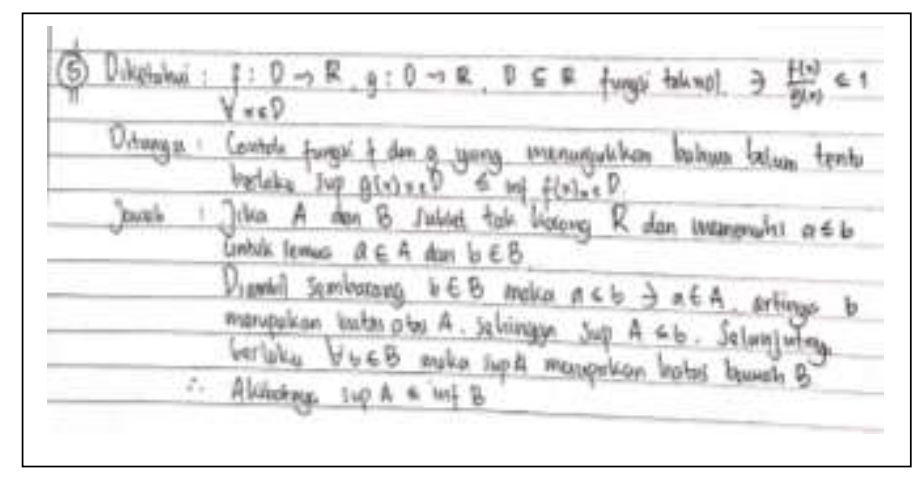

Figure 2. Test Result of S4 at Number 4 
Based on Figure 2, in question 4 the subject has not been able to compile evidence to give examples of the functions $\quad f(x)$ and $\quad g(x)$ so that $\quad \sup g(x) \leq \inf g(x)$, even though the flow of thinking is in the concept of set which was answered correctly. Then the completion steps written by the subject, the conclusion is that $\forall b \in B_{\text {then }}$ $\sup (A)$ is the lower limit of $\mathrm{B}$, so $\quad \sup A \leq \inf B$, is a wrong conclusion.

\section{Mathematical reasoning of subjects who have moderate reasoning skills in solving HOTS-}

\section{based math problems}

Overall, S1 and S7 subjects have been able to solve the questions, although they are not complete and have not used contradictory evidence. In detail there will be a picture of student work results S7.

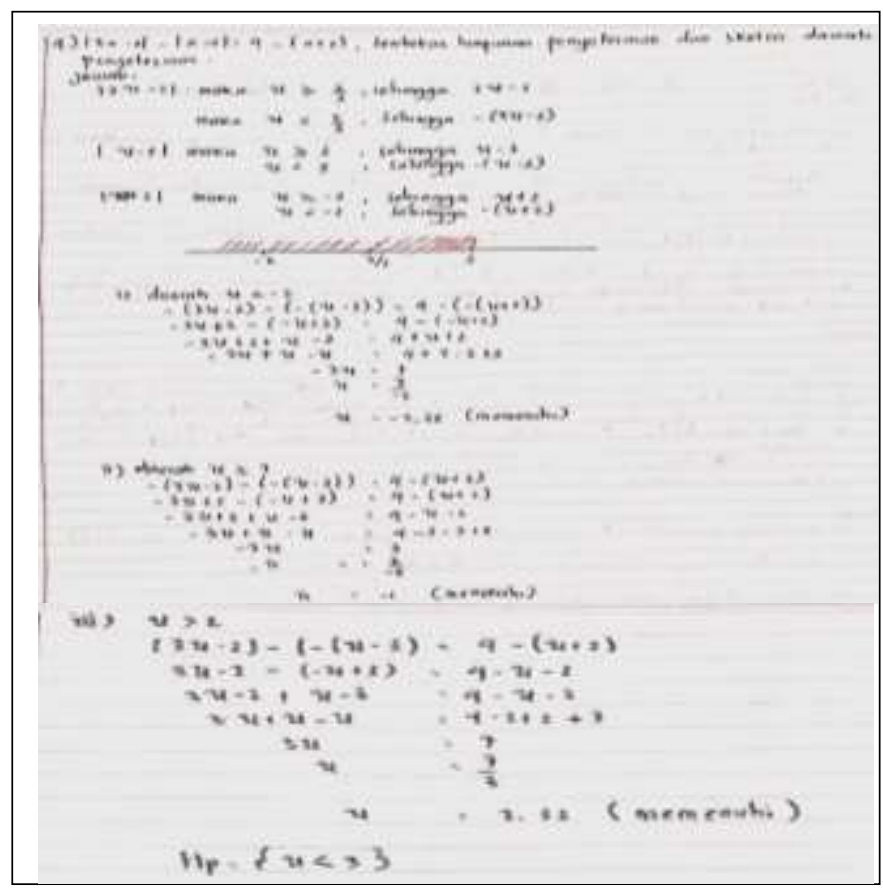

Figure 3.Test Result of S7 at Number 4

. In Figure 3, it can be seen that S7 is able to answer questions 1 and 2 . This means that S1 is able to solve HOTS-based real analysis questions which are at the creative and analyzing level. Whereas in problem 4, S7 is able to define the absolute value, however, the subject is wrong in determining the area of completion of the absolute value that meets. Subject only answered 1 correct completion area. 
Based on Figure 3, it can be seen that $\mathrm{S} 7$ is able to propose initial guesses to solve the absolute value equation. The subject starts with the correct step, namely defining the absolute value equation to find the solution area even though it is written differently from the actual definition. Based on the problem solving, the subject can only determine one correct area of solution, namely for $\quad x \leq 2$, in effect $|3 x-2|-|x-3|=4-|x+2|-(3 x-$ $2)-(-(x-3))=4-(-(x+2))$, so you get the solution for $\quad x=\frac{-7}{3}$

The Mathematical reasoning of subjects who have low reasoning skills in solving HOTSbased math problems

Based on the answers of the S-5 test, it can be said that they have not been able to correctly solve the HOTS-based real analysis test questions. The subject is unable to rewrite the known and questioned data. And also unable to compile steps in solving the problem. The following is an excerpt from the answers to the S- 5 written questions.

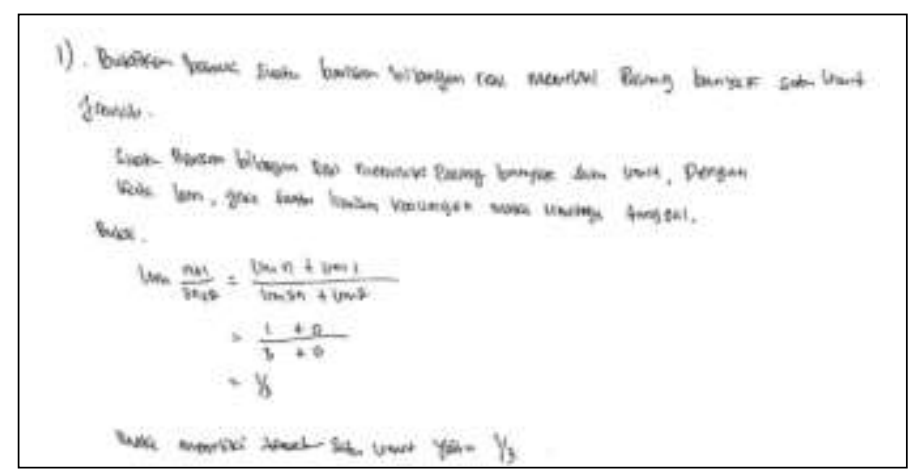

Figure 4.Test Result of S5 at Number 1

Based on Figure 4, it can be seen that $\mathrm{S} 5$ has not found a pattern in proving a theorem using the contradiction method. So that the conclusions drawn in solving the problem are also wrong.

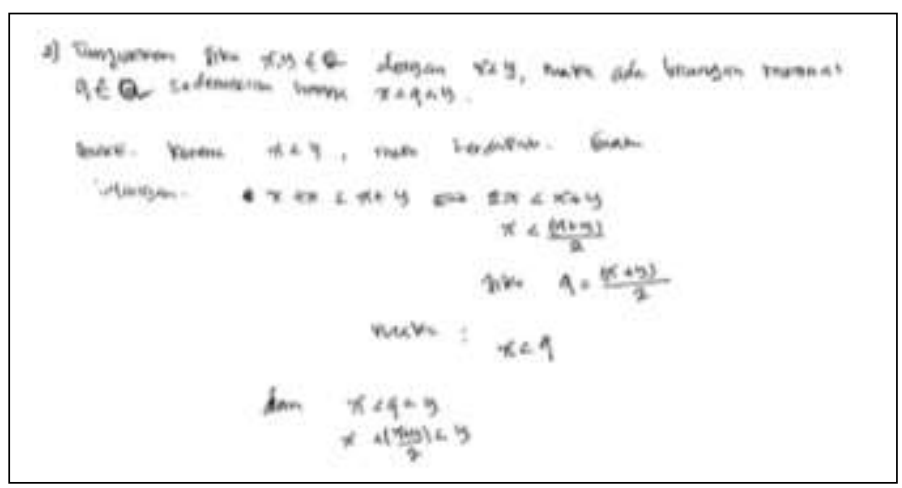

Figure 5.Test Result of S5 at Number 1 
In Figure 5, S5 answers the question with correct thinking logic. S5 showed that there is a real number $q=\frac{x+y}{2}$ so that if $x<y$ then $^{x}<q=\frac{x+y}{2}<y$. However, this answer is not the expected solution, because this problem should be solved using the rational number theorem.

\section{Student's Understanding of HOTS Oriented Question}

The results of the questionnaire on student understanding of HOTS-oriented questions were analyzed to determine the percentage of student understanding of each question item, which is shown in Figure 6.

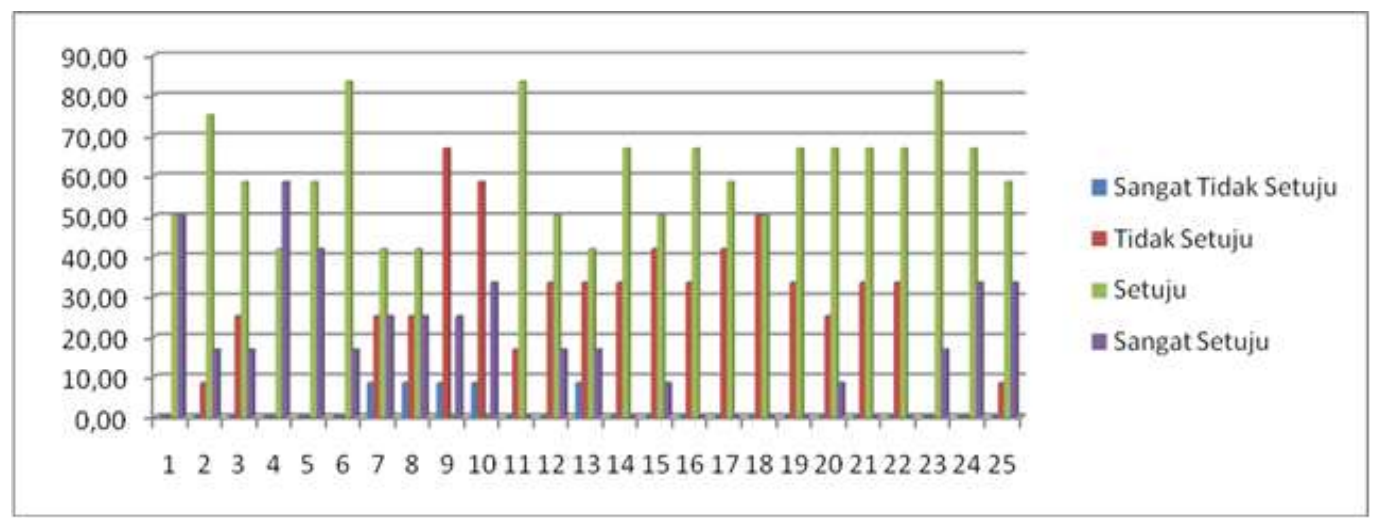

Figure 6. Distribution of Student Answers to Questionnaire Question Items

The indicator of understanding is used in Polya's Stages in (Phuntsho \& Dema, 2019) The results of the answers to the questionnaire were analyzed to determine the percentage of student understanding of each question item. The following is the student's response to each question item.

1. The ability to undertand questions.

The indicator of understanding the questions is represented by 8 questionnaire items. From these questions $20 \%$ of students answered strongly agree and $46.67 \%$ of students agreed. If you look more deeply, students who answered strongly agree and agree are dominated by students from high and medium groups. Meanwhile, students from the low group still had difficulty understanding the questions. This condition is supported by the analysis of student's written answers, where almost all of them are unable to rewrite what they know and what will be proven from these 
questions. This illustrates that students still need guidance in understanding problems, especially in proving theorems.

2. Planning For Problem

The indicator for planning questions is represented by 11 questionnaire items. Based on the results of the analysis of students' answers, it was found that $33 \%$ of students could not write down the known information in answering HOTS questions. As much as $50 \%$ of students answered that they were unable to use definitions and theorems in proof, and were unable to manipulate algebra in preparing problem solving. This condition is supported by an analysis of the answers to question no.4, students do not use the absolute price definition. In providing reasons for each step of solving the questions, $33 \%$ of students were unable to provide reasons or evidence for several solutions. This gives an idea that students do not understand well in planning and solving problems.

3. Finished as planned

The indicator for planning questions is represented by 6 questionnaire items. In this stage, it is divided into 2 activities, namely completing and checking again. Based on the results of the analysis of student answers, it was found that $33 \%$ were unable to check the validity of an argument and draw conclusions on the evidence that had been done. This condition causes students to draw wrong conclusions from the completion, or students to draw conclusions that are not in accordance with the steps that have been arranged in solving the problem

From the explanation above about student responses to understanding HOTS questions, it can be concluded that students do not understand HOTS questions well. This condition causes students to be unable to compile steps to solve problems and draw conclusions. In general, most students still have difficulties in proving a real analysis problem solving HOTS-oriented especially in proving the theorem. This shows that students' mathematical reasoning skills still need to be improved. This is in line with the statement (Agustyaningrum et al., 2019; Hakima et al., 2019) which says that students have difficulty proving. The student's ability to solve HOTS questions cannot be separated from the application of the learning that is being carried out. Therefore it is very important to choose 
the right learning model during the implementation of learning (Adijaya, 2018; Yusuf \& Widyaningsih, 2018; Zamista et al., 2020).

\section{CONCLUSION}

Based on the research that has been done, it is found that there is a relationship between students' mathematical reasoning abilities and the level of student understanding of HOTS-oriented questions, which is defined in the simple regression model, namely $\quad Y=71.54+0.009 X$. The linear regression model shows that the level of student understanding of HOTS-oriented questions has a positive effect on student learning outcomes.

Students' mathematical reasoning in solving HOTS-oriented real analysis problems can be concluded as follows : (1) Students with high mathematical reasoning abilities in solving real analysis problems have a tendency to fulfill the seven mathematical reasoning indicators very well. The student is able to carry out mathematical reasoning at each stage of real analysis problem solving and is able to work on HOTS level questions to analyze and create ; $(2)$ Students with moderate mathematical reasoning skills in solving real analysis problems have a tendency to carry out mathematical reasoning well. These students are only able to meet several indicators of mathematical reasoning at the problem solving stage, namely presenting written statements, solving problems as planned ; (3) Students with low mathematical reasoning skills in solving real analysis problems have a tendency to carry out mathematical reasoning less well. These students are not able to meet all indicators of mathematical reasoning. Students are not able to understand the questions well, so that students cannot complete the questions asked.

Based on the results of the research and discussion that has been concluded above, the researcher suggests that lecturers provide more training related to proof with the aim of improving students' mathematical reasoning abilities in real analysis subjects. For other researchers who are interested, they can try to dig further from this research or can do it ata different level and material with the same observation point of view or other observation points of view regarding student's mathematical reasoning. 


\section{ACKNOWLEDGMENTS}

Gratitude is conveyed to the Bung Hatta University Research and Community Service Institute (LPPM) for funding this research through the 2020 Higher Education Excellence Lecturer Research (PDUPT) scheme with contract letter No. 068-05 / LPPM-Research / Hatta / IX-2020 7 September 2020.

\section{REFERENCES}

Abadiyah Agustiana Zakiyatuddarul. (2016). Penalaran Matematika Dalam Argumentasi Kolektif Dalam Memecahkan Masalah Matematika Ditinjau dari Heterogenitas Kelompok Kemampuan Matematika. Universitas Negeri Surabaya.

Adamura, F., \& Susanti, V. D. (2018). Penalaran Matematis Mahasiswa Dalam Memecahkan Masalah Analisis Real Berdasarkan Kemampuan Berpikir Intuitif. Journal of Mathematics and Mathematics Education, 8(2), 156-172. https://doi.org/10.20961/jmme.v8i2.25852

Adijaya, N. (2018). Persepsi Mahasiswa dalam Pembelajaran Online "Pengembangan teori dari penelitian berjudul "persepsi mahasiswa terhadap materi ajar pada pembelajaran online" yang telah dipublikasi di Jurnal Eduscience Vol. 3/1. Wanastra: Jurnal Bahasa Dan Sastra, 10(2), 105-110. https://doi.org/10.31294/w.v10i2.3931

Agustyaningrum, N., Hanggara, Y., Husna, A., Abadi, A. M., \& Mahmudi, A. (2019). An analysis of students' mathematical reasoning ability on abstract algebra course. International Journal of Scientific and Technology Research, 8(12), 2800-2805.

As'ari, A. R., Ali, M., Basri, H., Kurniati, D., \& Maharani, S. (2019). Mengembangkan HOTS (High Order Thinking Skills) Melalui Matematika (I). Universitas Negeri Malang.

Dosinaeng, W. B. N. (2019). Analysis of students' higher order thinking skills in solving basic combinatorics problems. Math Didactic: Jurnal Pendidikan Matematika, 5(2), 133-147. https://doi.org/10.33654/math.v5i2.611

Fajar, S. (2014). Pembelajaran matematika : Cara Meningkatkan Kemampuan Berpikir Kritis Siswa (I). Graha IImu.

Hakima, L., Sukestiyarno, \& Dwidayanti, N. K. (2019). Analisis Kemampuan Penalaran Matematis pada Pembelajaran Problem Based Learning Berbantuan Modul Komik Etnomatematika. Seminar Nasional Pascasarjana, 1999, 1003-1007. 
Hanifah, A. N., Sa'adah, N., \& Sasongko, A. D. (2019). Hubungan Kemampuan Penalaran Matematis Dan Motivasi Belajar Siswa Smk Melalui Model Pembelajaran Hypnoteaching. Teorema: Teori Dan Riset Matematika, 4(2), 121. https://doi.org/10.25157/teorema.v4i2.2692

Keller, B. A., Hart, E. W., \& Martin, W. G. (2001). Illuminating NCTM's Principles and Standards for School Mathematics . School Science and Mathematics, 101(6), 292-304. https://doi.org/10.1111/j.1949-8594.2001.tb17960.x

Phuntsho, U., \& Dema, Y. (2019). Examining the Effects of Using Polya's Problem- solving Model on Mathematical Academic Achievement and Analyzing Ability of the Fourth Grade Students. Asian Journal of Education and Social Studies, 5(2), 1-8. https://doi.org/10.9734/ajess/2019/v5i230142

Sugiyono. (2013). Metode PenelitianPendidikan : Pendekatan Kuantitatif, Kualitatif dan R \& D. AlfaBeta.

Suryadi. (2011). Membangun Budaya Baru dalam Berpikir Matematika (1st ed.). Universitas Pendidikan Indonesia. https://fdokumen.com/download/membangun-budaya-barudalam-berpikir-matematika

Yusuf, I., \& Widyaningsih, S. W. (2018). Profil Kemampuan Mahasiswa Dalam Menyelesaikan Soal Hots Di Jurusan Pendidikan Fisika Universitas Papua. Jurnal Komunikasi Pendidikan, 2(1), 42. https://doi.org/10.32585/jkp.v2i1.63

Zamista, A. A., Rahmi, H., Sellyana, A., \& Desriyati, W. (2020). Persepsi Mahasiswa Terhadap Pembelajaran Dalam Jaringan Untuk Mata Kuliah Kalkulus. Jurnal THEOREMS (The Original Research of Mathematics), 5(1), 41. https://doi.org/10.31949/th.v5i1.2214 